\title{
KEMANDIRIAN KEUANGAN DAERAH DAN PERTUMBUHAN EKONOMI KABUPATEN/KOTA LAMPUNG TAHUN ANGGARAN 2014-2018
}

\author{
Fadeli Yusuf Afif ${ }^{1}$ \\ Ukhti Ciptawaty ${ }^{2}$
}

Fakultas Ekonomi dan Bisnis Universitas Lampung, Lampung, Indonesia ${ }^{1,2}$
Email: fadeliyusufafif@gmail.com ${ }^{1}$

\begin{abstract}
This study aims to analyze the independence and ability of regencies / cities and their effects on economic growth in Lampung Province. The method used is panel data analysis. The results showed that Bandar Lampung City was in a consultative relationship pattern, while 13 districts and 1 other city were in an instructive relationship pattern. Whereas based on the analysis of regional financial capability, Bandar Lampung City has a good relationship pattern category, the Metro City category of sufficient relationship pattern and South Lampung Regency and East Lampung Regency with less relationship pattern criteria. Whereas the other 11 districts are still in very poor category. Regression results show that the ratio of regional financial capacity has a negative and significant effect on the level of a (5\%) on economic growth, while regional financial independence has no effect on economic growth.
\end{abstract}

Keywords: Economic Growth; Fixed Effect Model; Regional Financial Capability; and Regional Financial Independence.

\begin{abstract}
ABSTRAK
Penelitian ini bertujuan untuk menganalisis kemandirian dan kemapuan kabupaten/kota serta pengaruhnya terhadap pertumbuhan ekonomi di Provinsi Lampung. Metode yang digunakan adalah analisis panel data. Hasil penelitian menunjukkan bahwa Kota Bandar Lampung berada pada pola hubungan konsultif, sedangkan 13 kabupaten dan 1 kota lainnya berada pada pola hubungan instruktif. Sedangkan berdasarkan analisis kemampuang keuangan daerah Kota Bandar Lampung memiliki kategori pola hubungan yang baik, Kota metro kategori pola hubungan cukup dan Kabupaten Lampung Selatan dan Lampung Timur dengan kriteria pola hubungan kurang. Sedangkan 11 kabupaten lainnya masih dalam kategori sangat kurang. Hasil regresi menujukkan bahwa rasio kemampuan keuangan daerah berpengaruh negatif dan signifikan pada tingkat $\alpha(5 \%)$ terhadap pertumbuhan ekonomi, sedangkan kemadirian keuangan daerah tidak berpengaruh terhadap pertumbuhan ekonomi.
\end{abstract}

Kata Kunci : Fixed Effect Model; Kemampuan Keuangan Daerah; Kemandirian Keuangan Daerah; dan Pertumbuhan Ekonomi. 


\section{PENDAHULUAN}

Teori pertumbuhan Solow mengatakan bahwa pertumbuhan ekonomi dipengaruhi oleh tingkat modal, tenaga kerja dan teknologi. Tingkat pembangunan manusia yang besar akan memmengaruhi kinerja ekonomi melalui tingkat penduduk sehingga produktifitas dan kreatifitas masyarakat mengalami peningkatan. Peningkatan pada produktivitas dapat meningkatkan output dan akan berdampak pada pertumbuhan ekonomi. Pertumbuhan ekonomi Indonesia telah mengalami dua guncangan krisis ekonomi yang terjadi pada tahun 1997 dan 2008.

Krisis ekonomi pertengahan tahun 1997 yang melanda dunia berdampak negatif bagi perekonomian dunia termasuk Indonesia. hal ini menyebabkan perekonomian dunia memburuk. Dalam UU No. 33 Tahun 2004 tentang Perimbangan Keuangan Antara Pemerintah Pusat dan Pemerintah Daerah menjadi tanda reformasi keuangan daerah, hasil revisi dari Undang-undang (UU) No. 22 Tahun 1999 dan UU No. 32 Tahun 2004 tentang Pemerintah Daerah serta UU No. 25 Tahun 1999.

Adanya Reformasi dalam pemerintahan saat ini semakin mendorong Otonomi Daerah menjadi kebutuhan masyarakat. Tujuan dari Otonomi Daerah adalah menjadikan daerah bebas untuk mengatur dirinya tanpa ada campur tangan pemerintah pusat melalui kemandirian dan kemampuan keuangan daerah. Hal ini menjadikan pemerintah daerah untuk dapat mengelola keuangan dalam rangka mencapai pertumbuhan ekonomi yang tinggi. 


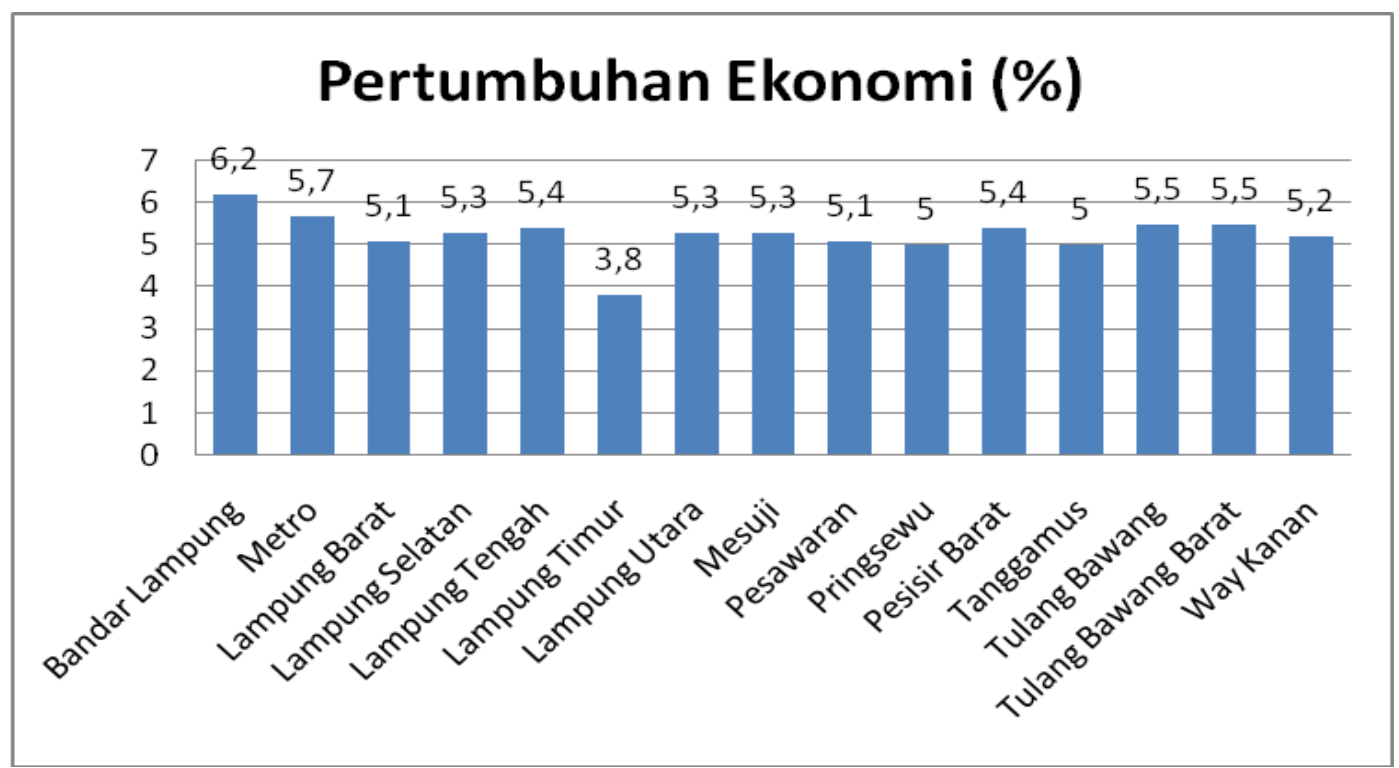

Sumber: Badan Pusat Statistik Provinsi Lampung, 2019

\section{Grafik 1.}

Pertumbuhan Ekonomi Kabupaten/Kota di Provinsi Lampung Tahun 2018

Grafik 1 menujukkan bahwa pertumbuhan ekonomi tahun 2018 tertinggi Kota Bandar Lampung yaitu 6,2 persen dan pertumbuhan ekonomi terendah di Kabupaten Lampung timur dengan nilai pertumbuhan ekonomi sebesar 3,8 persen, sedangkan pertumbuhan ekonomi Provinsi Lampung tahun 2018 adalah 5,25 persen. Kota Bandar Lampung memiliki pertumbuhan ekonomi tertinggi yang disebabakan karena kota tersebut menjadi pusat perekonomian di Provinsi Lampung. Salah satu kota yang memiliki peran dan tanggung jawab dalam memberikan pelayanan untuk masyarakat daerahnya adalah Kota Bandar Lampung.

Kemampuan keuangan daerah menjadi salah satu ciri yang menunjukkan daerah yang mampu malakukan otonomi daerah, artinya daerah harus mampu mengelola keuangan dan sumber daya yang dimiliki, mengelola dan menggunakan keuangan sendiri yang cukup memadai untuk membiayai 
penyelengaraan kegiatan pemerintahan daerah. Suatu daerah dikatakan otonom apabila PAD yang disumbangkan berkisar 30\% dari total APBD. (Desita, 2015). Disamping itu, terdapat daerah yang mampu melaksanakan otonomi daerah dengan mengelola sumber daya yang dimiliki, namun ada beberapa daerah yang mengalami kendala dalam menyelenggarakan tugas desentralisasi, mengingat sumber daya yang dimiliki terbatas. (Halim, 2011:253) menyatakan bahwa ciri utama suatu wilayah yang mampu menyelenggarakan otonomi memiliki ciri-ciri antara lain: 1). Kemampuan keuangan daerah adalah suatu daerah memiliki kemampuan dan wewenang untuk menggali dan mengelola keuangan daerah untuk mendanai penyelenggaraan kegiatan pemerintahannya. 2). Ketergantungan kepada bantuan pusat harus sekecil mungkin, sehingga pendapatan asli daerah dijadikan sumber keuangan terbesar dan berperan lebih besar terhadap kegiatan pemerintah daerah.

Perbedaan belanja antar daerah terdapat pada perbedaan potensi pajak dan retribusi daerahnya. Tingginya dana transfer daerah terhadap PAD dalam mendanai kegiatannya tidak memberikan contoh yang baik bagi pemerintah daerahnya, terdapat kajian empiris yang menyatakan bahwa tingginya ketergantungan pemerintah daerah pada transfer menyebabkan penurunan hasil kinerja pemerintahnya. Tujuan utama implementasi transfer dana ke daerah adalah untuk pemerataan fiskal antar daerah, perbaikan sistem perpajakan, dan koreksi ketidakefisienan fiskal yang muncul lintas daerah (Kuncoro, 2007 dalam Urip \& Rachmaeny, 2017).

Berdasarkan UU No. 33 Tahun 2004, menyatakan bahwa Dana Perimbangan terdiri dari Dana Alokasi Umum (DAU), Dana Alokasi Khusus 
(DAK), dan Dana Bagi Hasil (DBH). Dana transfer bertujuan untuk meminimalisir kesenjangan antar pemerintahan, selain itu juga untuk membantu mendanai kegiatannya. Menurut Halim, (2011) penerimaan daerah masih didominasi oleh dana Dana Alokasi Umum. Kuncoro, 2007 (dalam Urip \& Rachmaeny, 2017) juga menujukkan bahwa Pendapatan Asli Daera hanya berkontribusi 20 persen dari total benaja yang dilakukan.. Kondisi tersebut menggambarkan bahwa tujuan otonomi tidak tecapai yang mana daerah mampu mandiri dengan mengelola sumber daya yang dimiliki.

Tabel 1.

Data PAD, Dana Perimbangan dan TKDD Kabupaten/Kota Provinsi Lampung 2018

\begin{tabular}{|c|c|c|c|c|c|}
\hline \multirow[b]{2}{*}{ Kabupaten/Kota } & \multirow{2}{*}{$\begin{array}{c}\text { Pendapatan } \\
\text { Asli Daerah } \\
\text { (PAD) }\end{array}$} & \multirow{2}{*}{$\begin{array}{c}\text { Dana } \\
\text { Perimbangan } \\
\text { (DP) }\end{array}$} & \multirow{2}{*}{$\begin{array}{c}\text { Total } \\
\text { Transfer Ke } \\
\text { Daerah Dan } \\
\text { Dana Desa } \\
\text { (TKDD) }\end{array}$} & \multicolumn{2}{|c|}{ Rasio } \\
\hline & & & & $\begin{array}{c}\text { PAD/ } \\
\text { TKDD }\end{array}$ & $\begin{array}{c}\text { DP/ } \\
\text { TKDD }\end{array}$ \\
\hline Bandar Lampung & 788.377 .674 .850 & 1.345 .766 .066 .000 & 1.364 .968 .467 .075 & 57,76 & 98,59 \\
\hline Metro & 136.386 .374 .028 & 637.045.109.000 & 649.567 .025 .412 & 21,00 & 98,07 \\
\hline Lampung Barat & 45.153 .983 .659 & 860.612 .627 .000 & 984.064 .032 .647 & 4,59 & 87,45 \\
\hline Lampung Selatan & 218.376 .243 .132 & 1.414 .320 .659 .280 & 1.667 .654 .402 .050 & 13,09 & 84,81 \\
\hline Lampung Tengah & 153.971.205.759 & 1.826 .818 .636 .000 & 2.071 .152 .705 .561 & 7,43 & 88,20 \\
\hline Lampung Timur & 236.726 .568 .764 & 1.496 .913 .567 .235 & 1.729.207.994.709 & 13,69 & 86,57 \\
\hline Lampung Utara & 133.231 .503 .583 & 1.323 .932 .496 .797 & 1.456 .284 .820 .856 & 9,15 & 90,91 \\
\hline Mesuji & 41.025 .735 .777 & 621.059 .220 .200 & 738.307 .707 .754 & 5,56 & 84,12 \\
\hline Pesawaran & 59.844 .283 .386 & 950.990 .396 .000 & 1.114 .595 .911 .996 & 5,37 & 85,32 \\
\hline Pringsewu & 82.534 .500 .000 & 849.576.967.500 & 973.870 .400 .377 & 8,47 & 87,24 \\
\hline Pesisir Barat & 27.998.961.576 & 580.829 .778 .000 & 672.330 .831 .121 & 4,16 & 86,39 \\
\hline Tanggamus & 83.874.909.201 & 1.081 .717 .010 .000 & 1.323 .499 .952 .931 & 6,34 & 81,73 \\
\hline Tulang Bawang & 103.010 .560 .046 & 921.489 .260 .000 & 1.039 .731 .373 .834 & 9,91 & 88,63 \\
\hline $\begin{array}{l}\text { Tulang Bawang } \\
\text { Barat }\end{array}$ & 31.210 .500 .000 & 726.982 .144 .000 & 826.865 .033 .464 & 3,77 & 87,92 \\
\hline Way Kanan & 52.566 .752 .594 & 1.028 .471 .292 .000 & 1.204 .803 .514 .974 & 4,36 & 85,36 \\
\hline
\end{tabular}


Fadeli Yusuf Afif dan Ukhti Ciptawaty. Kemandirian Keuangan Daerah Dan Pertumbuhan.

Sumber: Direktorat Jenderal Perimbangan Keuangan, 2019

Tabel 1 menujukkan bahwa rasio PAD terhadap Total Transfer Ke Daerah Dan Dana Desa (TKDD) tahun 2018 tertinggi pada Kota Bandar Lampung dengan nilai 57,76 persen sedangkan rasio terendah yaitu pada Kabupaten Tulang Bawang Barat, dan pada rasio dana peringbangan terhadap Total Transfer Ke Daerah Dan Dana Desa (TKDD) tertinggi pada Kota bandar Lampung dengan nilai 98,58 persen sedangkan rasio terendah yaitu Kabupaten Tanggamus dengan nilai 81,73 persen.

Penerimaan maupun pengeluaran dan analisa terhadap kondisi keuangan daerah, keuangan daerah menjadi sumber informasi penting dalam pembuatan kebijakan untuk mengelola keuangan daerah dalam rangka menilai kemandirian dan kemampuan daerah. "Hubungan Situasional" dalam melaksanakan otonomi daerah dikenalkan Paul Hersey dan Kenneth Blanchard (Efendi \& Sri, 2011). 1). Pola Hubungan Instruktif, pemerintah daerah dinilai belum mampu melaksanakan otonomi daerah, sehingga kontribusi pemerintah pusat masih tinggi. 2). Pola Hubungan Konsultif, permerintah derah sudah dapat melaksanakan otonomi daerah meskipun masih sedikit, sehingga kontribusi pemerintah pusat sudah berkurang. 3). Pola Hubungan Partisipatif, pemerintah daerah dinilai sudah dinilai lebih mandiri, sehingga kontribusi atau peran pemerintah pusat berkurang lebih besar. 4). Pola Hubungan Delegatif, pemerintah daerah sudah mandiri sehingga tidak ada kontribusi dana dari pemerintah pusat.

Pada penelitian yang dilakukan Mujiwardhani (2008) melakukan penelitian di Kabupaten Cilacap, hasil menujukkan bahwa pada masa sebelum 
maupun selama otonomi daerah kemampuan keuangan daerah masih rendah. Hal ini menujukkan bahwa Kabupaten Cilacap belum mampu melaksanakan Otonomi Daerah, ditandai dengan besaran peran pemerintah pusat yang masih tinggi.

Penelitian sebelumnya dilakukan oleh Desita (2015) tentang kemampuan keuangan daerah dalam pelaksanaann otonomi daerah di Pekanbaru menujukkan bahwa rasio kemandirian keuangan daerah pada pola instruktif artinya peranan pemerintah pusat masih mendominasi dalam pembiayaan pelaksanaan kegiatan pemerintah dalam pembangunan daerahnya. Selanjutnya rasio derajat desentralisasi fiskal dalam kategori kurang yaitu 17,68 persen ini menggambarkan bahwa pemerintah belum mandiri. Indeks kemampuan rutin sebesar 37,01 persen yang menujukkan masih dalam skala kurang, artinya belanja rutin yang ditujukan untuk pencapaian tugas dan fungsi pemerintah belum dapat dibiayai pemerintah. Selanjutnya rasio keserasian sebesar 47,16 persen yang hampir sama dengan belanja pembangunan sebersar 40,70 persen. Selanjutnya rasio pertumbuhan yang mengalami pertumbuhan yang positif.

Keberhasilan dalam melaksanakan otonomi daerah dinilai melalui bagian keuangan yang menjadi salah satu penilaian penting dalam menyelanggaran otonomi suatu daerah. Pada penelitian sebelumnya hanya dilakaukan analisis mengenai kondisi kemandirian dan kemampuan keuangan daerah, sedangkan penelitian ini bertujuan untuk menganalisis pengaruh tingkat rasio kemampuan daerah dan tingkat rasio kemandirian daerah serta menganalisis pengaruh rasio kemampuan dan kemandirian daerah terhadap pertumbuhan ekonomi kabupaten/kota di Provinsi Lampung periode 2014-2018. 


\section{METODE PENELITIAN}

Jenis penilitian ini adalah deskriptif kuantitatif dan data dalam penelitian ini adalah data sekunder, terdiri dari data pertumbuhan ekonomi (PE), kemandirian keuangan daerah (KMD), dan kemampuan keungan daerah (KKD) dengan populasi seluruh Kabupaten/Kota Lampung pada tahun 2014-2018 yang diperoleh dari Badan Pusat Statistik, dan Direktoral Jenderal Perimbangan Keuangan. Adapun untuk menganalisis kemandirian dan kemampuan keuangan daerah adalah sebagai berikut (Wulandari, 2001):

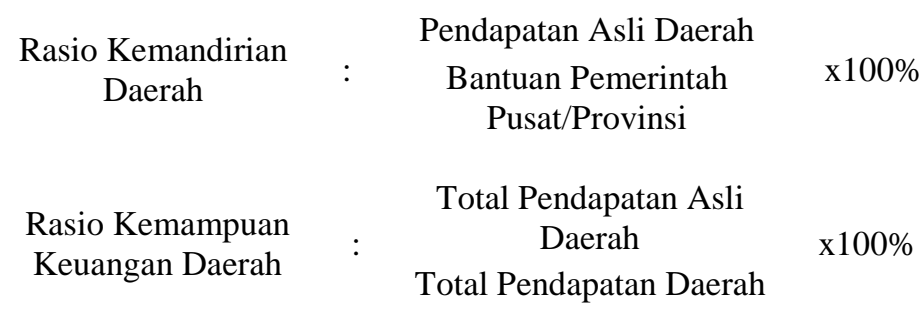

Sedangkan untung menganalisis pengaruh kemandirian dan kemampuan keuangan daerah terhadap pertumbuhan ekonomi mengguanakan regresi data panel dengan model sebagai berikut:

$\mathrm{PE}_{\mathrm{it}}=\beta_{0}+\beta_{1} \mathrm{RMD}_{\mathrm{it}}+\beta_{2} \mathrm{RKD}_{\mathrm{it}}+\varepsilon_{\mathrm{it}}$

Keterangan:

$\mathrm{PE}_{\mathrm{it}} \quad=$ Pertumbuhan Ekonomi

$\mathrm{RMD}_{\mathrm{it}}=$ Kemandirian Keuangan Daerah

$\mathrm{RKD}_{\text {it }}=$ Kemampuan Keuangan Daerah

$\beta_{0} \quad=$ Intersep

$\beta_{\text {it }} \quad=$ Koefisien Regresi

$\varepsilon_{\text {it }} \quad=$ Error Term

$\mathrm{i} \quad=1,2, \ldots . \mathrm{n}$, menunjukkan jumlah individu (cross section)

$\mathrm{t} \quad=1,2, \ldots . \mathrm{t}$, menunjukkan runtun waktu (time series) 
Metode panel data merupakan alat analisis yang digunakan dalam penelitian ini dengan menggunakan bantuan E-Views 9.0. Menurut Gujarati \& Porter (2008, p.591) data panel adalah kombinasi dari cross section dan data time series. Data cross section merupakan data yang dikumpulkan pada waktu yang sama dari beberapa daerah, perusahaan atau individu. Sedangkan data time series merupakan data yang disusun berdasarkan urutan waktu, seperti data harian, bulanan, kuartal atau tahunan. Penggabungan kedua jenis data dapat dilihat bahwa variabel terikat imbal hasil sukuk terdiri dari beberapa unit individu (cross section) namun dalam berbagai periode waktu (time series) (Baltagi, 2008, p.292).

Pemilihan Metode Regresi Data Panel. Estimasi data panel yang terdiri dari 3 macam metode yaitu Common Effect Model, Fixed Effect Model, dan Random Effect Model. Selanjutnya untuk memilih model tersebut dilakukan tiga tahap pengujian yaitu uji Chow, uji Hausman, dan Uji LM test.

Pengujian normalitas dilakukan untuk menguji apakah dalam model regresi, variabel dependen dan independen memiliki distribusi normal atau tidak. Residual dikatakan memiliki distribusi normal jika Jarque Bera >chi-squares, dan atau probabilita ( $p$-value $)>\alpha=5 \%$ (Gujarati, 2010).

Uji multikolinieritas adalah deteksi yang menujukkan apakah data model regresi yang digunakan memiliki hubungan antar variabel bebas. Dengan rule of thumb, jika koefisien korelasi kurang dari 0,80 maka dapat disimpulkan bahwa ada masalah multikolinieritas pada model yang digunakan (Widarjono, 2018).

Uji heteroskedastisitas bertujuan untuk mendeteksi adanya penyimpangan pada asumsi homoskedastisitas yang tidak konstan. Hasil regresi akan 
menujukkan misleading jika model regresi terkena masalah heteroskedastisitas (Gujarati, 2010). Uji heteroskedasticitas dilakukan dengan membandingkan $O b s^{*} R$-Squared dengan $\chi^{2}$ (Chi-Square) tabel. Jika nilai $O b s * R$-Squared lebih besar dari $\chi^{2}$ tabel, maka tidak ada heteroskedastisitas pada model.

Uji autokorelasi bertujuan untuk mendeteksi apakah ada hubungan antara pengganggu atau residual dalam model regresi dengan cara deteksi yaitu menggunakan Breusch-Godfrey Serial correlation LM Test dengan membandingkan nilai Obs*R Square dengan nilai Chi-square. (Gujarati, 2010)

Uji t digunakan untuk melihat adanya signifikansi pengaruh secara parsial dari variabel bebas terhadap variabel terikat pada signifikansi $\alpha=5$ persen ceteris paribus. Dalam hal ini akan nilai antara t-hitung dengan t tabel dengan kriteria pengujian jika $\mathrm{t}$ tabel $>\mathrm{t}$ statistik, maka $\mathrm{H}_{0}$ diterima $\mathrm{Ha}$ ditolak. Artinya secara parsial koefisien regresi variabel bebas tidak memiliki pengaruh signifikan terhadap variabel terikat dan sebaliknya.

Uji F statistik digunakan untuk mengetahui pengaruh seluruh variabel bebas terhadap variabel terikat secara simultan atau bersama-sama. Kriteria pengujian jika $\mathrm{F}$ tabel $>\mathrm{F}$ statistik, maka $\mathrm{H}_{0}$ diterima $\mathrm{Ha}$ ditolak. Artinya koefisien regresi variabel bebas secara bersama-sama tidak berpengaruh signifikan terhadap variabel bebas dan sebaliknya.

Uji koefeisin determinasi dilakukan untuk melihat seberapa besar pengaruh variabel bebas terhadap variabel terikat yang digunakan dalam penelitian. Jika nilai $\mathrm{R}^{2}$ mendekati 1, maka variabel bebas yang digunakan mampu menjelaksan dengan baik variasi dari variabel terikatnya. 
HASIL DAN PEMBAHASAN

Tabel 2.

Rasio Kemandirian Keuangan Daerah Kabupaten/Kota Di Provinsi Lampung Tahun 2014-2018 dalam Rata-rata

\begin{tabular}{lcc}
\hline \multicolumn{1}{c}{ Kabupaten/Kota } & $\begin{array}{c}\text { Rasio Kemandirian } \\
\text { Keuangan Daerah (\%) }\end{array}$ & Pola Hubungan \\
\hline Bandar Lampung & 26,55 & Konsultatif \\
Metro & 15,47 & Instruktif \\
Lampung Barat & 5,62 & Instruktif \\
Lampung Selatan & 10,13 & Instruktif \\
Lampung Tengah & 6,05 & Instruktif \\
Lampung Timur & 7,36 & Instruktif \\
Lampung Utara & 7,67 & Instruktif \\
Mesuji & 3,79 & Instruktif \\
Pesawaran & 3,97 & Instruktif \\
Pringsewu & 6,60 & Instruktif \\
Pesisir Barat & 3,15 & Instruktif \\
Tanggamus & 3,05 & Instruktif \\
Tulang Bawang & 3,48 & Instruktif \\
Tulang Bawang Barat & 4,28 & Instruktif \\
Way Kanan & 4,22 & Instruktif \\
\hline
\end{tabular}

Sumber: Olahan Peneliti, 2019

Dari Tabel 2 dapat dijelaskan bahwa Kota Bandar Lampung berada pada pola hubungan konsultif, sedangkan 13 kabupaten dan 1 kota lainnya berada pada pola hubungan instruktif. Hal ini menunjukkan bahwa campur tangan pemerintah pusat sudah mulai berkurang di Kota Bandar Lampung, sedangkan peran pemerintah pusat di 13 kabupaten dan 1 kota lainnya lebih dominan daripada pemerintah daerah. Hasil tersebut menjelaskan bahwa Kota Bandar Lampung 
sedikit lebih mampu melaksanakan otonomi daerah.

Tabel 3.

Rasio Kemampuan Keuangan Daerah Kabupaten/Kota Di Provinsi Lampung Tahun 2014-2018 dalam Rata-rata

\begin{tabular}{lcc}
\hline \multicolumn{1}{c}{ Kabupaten/Kota } & $\begin{array}{c}\text { Rasio Kemampuan } \\
\text { Keuangan Daerah }(\boldsymbol{\%})\end{array}$ & Pola Hubungan \\
\hline Bandar Lampung & 40,41 & Baik \\
Metro & 21,69 & Cukup \\
Lampung Barat & 7,50 & Sangat Kurang \\
Lampung Selatan & 14,84 & Kurang \\
Lampung Tengah & 8,27 & Sangat Kurang \\
Lampung Timur & 19,04 & Kurang \\
Lampung Utara & 8,89 & Sangat Kurang \\
Mesuji & 4,76 & Sangat Kurang \\
Pesawaran & 5,35 & Sangat Kurang \\
Pringsewu & 8,91 & Sangat Kurang \\
Pesisir Barat & 4,46 & Sangat Kurang \\
Tanggamus & 4,11 & Sangat Kurang \\
Tulang Bawang & 5,56 & Sangat Kurang \\
Tulang Bawang Barat & 5,56 & Sangat Kurang \\
Way Kanan & 5,55 & Sangat Kurang \\
\hline Sum: Olang
\end{tabular}

Sumber: Olahan Peneliti, 2019

Dari Tabel 3 dapat dijelaskan bahwa Kota Bandar Lampung memiliki kategori pola hubungan yang baik yaitu dengan rata-rata rasio kemampuan keuangan daerah sebesar 40,41\%, hal ini mengartikan bahwa Pendapatan Asli Daerah berkemampuan baik untuk mendanai pembangunan di daerahnya. Selanjutnya Kota metro pada posisi kedua dengan kategori pola hubungan cukup dengan rata-rata rasio kemampuan keuangan daerah sebesar 21,69\% dan Kabupaten Lampung Selatan dan Lampung Timur dengan kriteria pola hubungan kurang dengan rata-rata rasio kemampuan keuangan daerah masing-masing sebesar 14,84\% dan 19,04\%. Sedangkan 11 kabupaten lainnya masih dalam kategori sangat kurang rata-rata rasio kemampuan keuangan daerah $<9,00 \%$. Hal ini menujukkan bahwa kemampuan PAD membiayai pembangunan di 11 
kabupaten masih sangat kurang atau dalam artian pemerintah daerah masih mengandalkan bantuan dana dari pemerintah pusat.

Uji Pemilihan Model. Berdasarkan hasil uji chow nilai Probability $(0,000)<\alpha$ $(0,05)$ maka fixed effect model adalah model terbaik yang akan digunakan dibandingkan dengan common effect model. Berdasarkan hasil uji hausman nilai Probability $(0,000)<\alpha(0,05)$ fixed effect model adalah model terbaik yang akan digunakan dibandingkan dengan random effect model.

Tabel 4.

Hasil Regresi Fixed Effect Model

\begin{tabular}{ccccc}
\hline Variable & Coefficient & Std. Error & t-Statistic & Prob. \\
\hline C & 5,574558 & 0,113119 & 49,28060 & 0,0000 \\
RKD & $-0,028165$ & 0,006263 & $-4,497317$ & 0,0000 \\
RKK & 0,028165 & 0,015104 & 0,736742 & 0,4642 \\
\hline \multicolumn{3}{c}{ R-squared 0,810591 } & F-statistic 15,51348 \\
\hline \multicolumn{3}{c}{ Adjusted R-squared 0,758340 } & Durbin-Watson stat 1,633577 \\
\hline
\end{tabular}

Sumber: Hasil Olahan Eviews 9.0, 2019

$\mathrm{PE}=5,574558-0,028165 \mathrm{RKD}+0,028165 \mathrm{RKK}$

Koefisien konstanta menujukkan angka 5,5746 hal ini berarti bahwa, jika seluruh variable bebas sama dengan nol maka perumbuhan ekonomi sebesar 5,5746\%. Variabel rasio kemampuan keuangan daerah berpengaruh negatif dan signifikan pada tingkat $\alpha(5 \%)$ terhadap pertumbuhan ekonomi, dimana jika rasio kemampuan daerah meningkat sebesar $1 \%$ menyebabkan pertumbuhan ekonomi turun sebesar 0,0282\%. Simanjuntak \& Imam (2015) menatakan bahwa peningkatan rasio kemampuang kuangan daerah di Jawa Barat justu menekan pertumbuhan ekonomi periode 2008-2011, hal ini mengindikasikan peningkatan pada risiko dalam otonomi daerah sehingga pertumbuhan ekonomi menurun. Variabel rasio kemandirian keuangan tidak berpengaruh signifikan pada tingkat $\alpha$ 
Fadeli Yusuf Afif dan Ukhti Ciptawaty. Kemandirian Keuangan Daerah Dan Pertumbuhan.

(5\%) terhadap pertumbuhan ekonomi. Rante, Muhmmad \& Andi (2017) menyatakan bahwa peningkatan rasio kemandirian keuangan daerah mengingkatkan pertumbuhan ekonomi tetapi tidak signifikan.

Pengujian Asumsi Klasik. Dari hasil pengujian dapat disimpulkan bahwa data terdistribusi normal, hal ini ditunjukkan dengna nilai probabilitas JarqueBera 0,0981 lebih besar dari $\alpha=0,05$.

Tabel 5.

Hasil Uji Multikolinieritas

\begin{tabular}{ccc}
\hline Variabel & RKD & RKK \\
\hline RKD & 1 & 0.4558 \\
RKK & 0.4558 & 1 \\
\hline
\end{tabular}

Sumber: Hasil Olahan Eviews 9.0, 2019

Hasil pengujian multikolinieritas pada Tabel 5, masing-masing variabel bebas memiliki nilai koefisien $<0,80$, sehingga dapat ditarik kesimpulan bahwa tidak ada hubungan antara variabel bebas dalam model regresi yang digunakan.

Tabel 6.

Hasil Uji Heteroskedastisitas

\begin{tabular}{cccc}
\hline Variabel Terikat & $\begin{array}{c}\text { Chi Square } \\
\text { Statistik }\end{array}$ & $\begin{array}{c}\text { Chi Square } \\
\text { Tabel }\end{array}$ & Kesimpulan \\
\hline 1 & 16,5609 & 5,99148 & Homoskedastisitas \\
\hline
\end{tabular}

Sumber: Hasil Output Eviews 9.0, 2019

Pada Tabel 6 ditunjukkan bahwa Chi Square Statistik $(16,5609)>C h i$

Square Tabel $(5,99148)$ dengan degree of freedom sebesar variabel bebas $=2$ dan tingkat signifikansi 5 persen. Hal ini dapat diartikan bahwa $\mathrm{H}_{0}$ diterima maka dalam model regresi tidak ada masalah heterokedastisitas.

Tabel 7.

Hasil Uji Autokorelasi

\begin{tabular}{cccc}
\hline $\begin{array}{c}\text { Variabel } \\
\text { Terikat }\end{array}$ & $\begin{array}{c}\text { Chi Square } \\
\text { Statistik }\end{array}$ & $\begin{array}{c}\text { Chi Square } \\
\text { Tabel }\end{array}$ & Kesimpulan \\
\hline
\end{tabular}




\begin{tabular}{cccc}
1 & 11,09754 & 5,99148 & Bebas Auotokorelasi \\
\hline Sumber: Hasil Output Eviews 9.0,2019 & & \\
Pada Tabel 7 ditunjukkan bahwa Chi Square Statistik $(7,504475)>$ Chi
\end{tabular}
Square Tabel $(5,99148)$ pada degree of freedom sebesar variabel kelambanan $=2$ dan tingkat signifikansi 5\%. Hal menujukkan bahwa $\mathrm{H}_{0}$ diterima maka dalam model regresi tidak ada masalah autokorelasi.

Pengujian Hipotesis Statistik. Uji bertujuan untuk melihat signifikasi dari pengaruh variabel bebas secara parsial terhadap variabel terikat. $d f=\mathrm{n}-\mathrm{k}-1$ (75-21) $=72$ dengan $\alpha=0,05$.

Tabel 8. Hasi Uji-t

\begin{tabular}{ccccc}
\hline Variable & t-Statistic & t-Tabel & Prob. & Kesimpulan \\
\hline RKD & $-4,4973$ & 1,66629 & 0,0000 & $\mathrm{H}_{0}$ ditolak \\
RKK & 0,73674 & 1,66629 & 0,4642 & $\mathrm{H}_{0}$ diterima \\
\hline
\end{tabular}
Sumber: Hasil Output Eviews 9.0, 2019

Dari hasil uji-t disimpulkan bahwa rasio kemandirian keuangan daerah secara parsial berpengaruh negatif dan signifikan terhadap pertumbuhan ekonomi, sedangkan rasio kemampuan keuangan daerah secara parsial tidak berpengaruh signifikan.

Uji F statistik bertujuan untuk melihat apakah variabel bebas yang digunakan mempengaruhi variabel terikatnya secara bersama-sama. $d f_{l}=\mathrm{n}-\mathrm{k}-1$ $(75-2)=73 d f_{2}=\mathrm{k}-1(2-1)=1$ dengan $\alpha=0,05$. Hasil f-statistik adalah sebesar 15,513 lebih besar dibandingkan dengan $\mathrm{F}$ tabel yaitu 3,97, hal ini menunjukkan bahwa variabel rasio kemandirian keuangan daerah dan rasio kemampuan keuangan daerah secara bersama-sama mempengaruhi pertumbuhan ekonomi.

Hasil $\mathrm{R}^{2}$ menujukkan nilai 0,8106 hal ini menunjukkan bahwa rasio 
kemandirian dan kemampuan keuangan daerah mampu menjelaskan sebesar 81,06 persen pertumbuhan ekonomi sedangkan sisanya 19,94 persen adalah variabel yang tidak masukkan ke dalam penelitian.

\section{SIMPULAN DAN SARAN}

Hasil penelitian menujukkan bahwa Kota Bandar Lampung berada pada pola hubungan konsultif, sedangkan 13 kabupaten dan 1 kota lainnya berada pada pola hubungan instruktif. Hasil analisis kemampuan keuangan daerah menujukkan bahwa Kota Bandar Lampung memiliki kategori pola hubungan yang baik. Selanjutnya Kota metro pada posisi kedua dengan kategori pola hubungan cukup, Kabupaten Lampung Selatan dan Lampung Timur dengan kriteria pola hubungan kurang. Sedangkan 11 kabupaten lainnya masih dalam kategori sangat kurang. Sedangkan hasil regresi menujukkan bahwa rasio kemampuan keuangan daerah berpengaruh negatif dan signifikan pada tingkat $\alpha(5 \%)$ terhadap pertumbuhan ekonomi dan rasio kemandirian keuangan daerah tidak berpengaruh signifikan.

Dalam upaya peningkatan kemampuan keuangan daerah dalam rangka mendanai pengeluaran daerah 13 kabupaten dan satu kota perlu meningkatkan pendapatan asli daerah (PAD) dengan cara mengelola sumberdaya yang dimiliki daerahnya, sehingga mampu melaksanakan otonomi daerah seperti Kota Bandar Lampung. Untuk penelitian selanjutnya disarankan untuk menggunakan variabel yang menjadi faktor utama yang mempengaruhi pertumbuhan ekonomi seperti modal dan tenaga kerja. 


\section{REFERENSI}

Abdul, H. (2004). Manajemen Keuangan Daerah (Edisi Revisi). Yogyakarta: UPP AMP YKPN.

Akai, N., \& Masayo S. (2002). Fiscal Decentralization Contributes to Economic Growth: Evidence from State-Level Cross-Section Data for the United States. Journal of Urban Economics. (52), 93-108. https://doi.org/10.1016/S0094-1190(02)00018-9

Arsyad, L. (1999). Pengantar Perencanaan dan Pembangunan Ekonomi Daerah. Edisi Pertama. Penerbit BPFE. Yogyakarta.

Davoodi, H., \& Heng, F. Z. (1998). Fiscal Decentralization and Economic Growth: A Cross-Country Study. Journal of Urban Economics, (43), 244257

Desita, P. N. (2015). Analisis Kemampuan Keuangan Daerah dalam Mendukung Pelaksanaan Otonomi Daerah Kota Pekanbaru (2010-2014). Jom FEKOM, 2(2), 1-13.

Efendi, D., \& Sri, W. (2011). Analisis Perkembangan Kemampuan Keuangan Daerah Dalam Mendukung Pelaksanaan Otoda di Kabupaten Nganjuk. Seminar Nasional Ilmu Ekonomi Terapan, Fakultas Ekonomi UNIMUS

Halim, A. (2011). Pengelolaan Keuangan Daerah. ( $3^{\text {th }}$ ed.). UPP AMP YKPN.

Gujarati, D.N., \& Porter, D.C. (2010). Dasar-Dasar Ekonometrika, (5 ${ }^{\text {th }}$ ed.). Jakarta: Salemba Empat

Kuncoro, H. (2007). Perilaku Asimetris Pemerintah Daerah Kota dan Kabupaten Atas Perubahan Besaran Transfer dari Pemerintah Pusat. Accounting Conference Faculty of Economics, Universitas Indonesia

Naumets, I. (2003). Fiscal Decentralization and Local Public Sector Efficiency, National University of Kiew.

Ndadari, A. (2008). Perilaku Asimetris Pemerintah Daerah Terhadap Pemerintah Pusat. $2^{\text {nd }}$ konferensi UKWMS, Surabaya 6 September 2008.

Oates, W. (1999). An Easy of Fiscal Federalism. Journal of Economics Literature (37), 1120-1149.

Rante, A., Muhmmad, S.M., \& Andi, P. (2017). Analisis Kemandirian Keuangan Daerah. Inovasi, 13(2).

Sakti, A. F. (2007). Analisis Perkembangan Kemampuan Keuangan Daerah Dalam Mendukung Pelaksanaan Otonomi Daerah Di Kabupaten Sukoharjo. Surakarta: UMS 
Simanjuntak, T.H., \& Imam, M. (2015). Empirical Study about The Interaction Between Equalization Funds, Regional Financial and Human Development Index in Regional Economic. International Journal of Economics and Finance, 7(1), https://10.5539/ijef.v7n1p192

Theiben, U. (2001). Fiscal Decentralisation \& Economic Growth in High-Income Oecd Countries. Working Paper, Economic Policy Research Institutes.

Thornton, J. (2007). Fiscal Decentralization and Economic Growth Reconsidered. Journal of Urban Economics, (61), 64-70. https://doi.org/10.1016/j.jue.2006.06.001

Undang-Undang No. 33 Tahun 2004 tentang Perimbangan Keuangan Antara Pemerintah Pusat dan Pemerintah Daerah

Urip, T. P., \& Rachmaeny, I. (2017). Analisis Flypaper Effect Pengelolaan Keuangan Daerah di Kota Jayapura. Jurnal Manajemen \& Bisnis, 1(2), 9-21

Widardjono, A. (2018). Ekonometrika. (5 $5^{\text {th }}$ ed.). Yogyakarta: UPP STIM YKPN.

Wulandari, A. (2001). Kemampuan Keuangan Daerah Studi Kasus Kota Jambi dalam Pelaksanaan Otonomi Daerah. Jurnal Kebijakan dan Administrasi Publik, (2). https://doi.org/10.22146/jkap.8441

Vaznquez, J.M., \& Robert M.M. (2001). Fiscal Decentralization and Economic Growth. Journal Urban Economics. https://doi.org/10.1016/S0305750X(03)00109-8

Xie, D. (1999). Fiscal Decentralization and Economic Growth in the United States. Journal of Urban Economics (45), 228-239. https://doi.org/10.1006/juec.1998.2095

Zhang, T \& Heng, F. Z. (1998). Fiscal Decentralization, Public Spending, and Economic Growth in China. Journal of Public Economics (67), 221-240. https://doi.org/10.1016/S0047-2727(97)00057-1 